\title{
The Role of Communication in Organizational Conflict Management at PT. Sinar Makmur Nusa Tenggara
}

\author{
${ }^{1}$ Yovita Marsha Listyono \\ Universitas Airlangga Surabaya, Jl. Dharmawangsa Dalam, Surabaya, Indonesia. \\ E-mail: 1yovitamarsha@gmail.com
}

\begin{abstract}
The sales team of PT. Sinar Makmur Timur, Nusa Tenggara area was formed in May 2019 and has been by the company standards in October 2019. In January 2020, the first conflict arose with the absence of the Sales Division during the morning briefing. Then the other conflicts have sprung up between the Sales Division and Area Sales Manager. This research focuses on the role of communication in organizational conflict management, especially the conflict between the Area Sales Manager and the Sales Division at PT. Sinar Makmur Timur Nusa Tenggara area. The approach to this research is a qualitative approach with a case study method. The results insulted that (1) the conflict is caused by the Sales Division which didn't implement the Standard Operating Procedure (SOP). (2) The conflict resolution uses the team management style from $R$. Blake \& Mouton, the collaborative style from Thomas \& Kilmann conflict management, and the integrative negotiation. (3) Communication plays a role in conflict management at PT. Sinar Makmur Timur Nusa Tenggara as the conflict itself as well as a means of conflict resolution. (4) The organizational communication approach in PT. The Sinar Makmur Timur Nusa Tenggara area is a classic approach.
\end{abstract}

Keywords: conflict management, organizational communication, organizational conflict

\section{INTRODUCTION}

Orang Tua (OT) Group is one of the consumer goods company in Indonesia. Sourced from Company Profile, OT Group was the first company that made traditional healthy drink products in Semarang in 1948. From a healthy drink, then it is developed by producing other products. In 1984, OT expanded to consumer goods started from producing toothpaste Formula.

In implementing sales distribution activity, OT established companies that specifically run in a distribution activity, one of them is PT. Sinar Makmur Timur. PT. Sinar Makmur Timur is a distribution company operated in several areas. Specifically, the distribution areas involve Kalimantan (Province of West Kalimantan, East Kalimantan, North Kalimantan), Nusa Tenggara (Province of West Nusa Tenggara and East Nusa Tenggara), Maluku, Sulawesi (Province of North Sulawesi, West Sulawesi, Central Sulawesi, Southeast Sulawesi, South Sulawesi), and Papua (Province of Papua and West Papua).

Previously, the Nusa Tenggara area was merged with the Kalimantan area. Then, the Nusa Tenggara area was considered to have potential and decided to form a specific sales division on Mei 2019. Initially, there was only one person in the Sales Division. However, the company standard determines that the Sales Division should minimally consist of three people. The new sales team was established in October 2019 according to company standards. West Nusa Tenggara has a Sales Manager and three people in the Sales Division. Then, in East Nusa Tenggara, there is a Sales Manager and a Sales Division.

This company has sales activity from agents level until small shops. Besides that, the sales conducted also 
Yovita Marsha Listyono. The Role of Communication in Organizational Conflict...

involve the distribution in HORECA (hotels, restaurants, and cafes). Every Salesperson is required to visit 10 hotels, 14 restaurants, and 15 cafes in one day. According to the number of employees, in West Nusa Tenggara area are conducted by three Salesperson, one person for each of HORECA, respectively. Then, in East Nusa Tenggara is only conducted by a Salesperson and a Sales Manager for the three distribution focus.

Distribution activities run well after the team was formed. In January 2020 occurred the first conflict between the Area Sales Manager and Sales Division. The first conflict occurred because the Sales Division had an absence when briefing in the morning. Based on the interview results with the Area Sales Manager of PT. Sinar Makmur Timur in Nusa Tenggara area, Timothius Richard Punuh, the absence of the Sales Division when morning briefing is considered with the Sales Division that did not obtain the sales turnover. As a result, the sales turnover in January 2020 was not achieved.

The researcher will examine the communication role in conflict management of PT. Sinar Makmur Timur in Nusa Tenggara area. Organizational conflict in this study refers to the organizational conflict between the Area Sales Manager and the Sales Division. Conflict is considered as consequences of termination, damage, deterioration, and fault in communication (Aula \& Siira, 2010). From that quotation, the researcher is assumed that there are communication roles in conflict management of PT. Sinar Makmur Timur in Nusa Tenggara area.

The research with the same topic had conducted by Ani Yuningsih (2011) entitled "Organizational Communication Implementation of Conflict Management". Aditya Kurnia Dani (2016) was also conducted the same research entitled "The Relationship of Organizational Communication and
Organizational Commitment in Conflict Management at the Teachers of Sekolah Islam Bunga Bangsa Samarinda". Both of the research will be the comparison in reading how the communication role of conflict management.

\section{METHOD}

This study uses a qualitative approach. Frels explained that qualitative research aims to explore, explain, and investigate a phenomenon (Onwuegbuzie et al., 2012). This study elaborates in detail the communication role of organizational conflict management between the Area Sales Manager and the Sales Division in PT. Sinar Makmur Timur in Nusa Tenggara area. The type of study used is descriptive research. Sandelowski mentioned that descriptive-qualitative research aims to naturally explain a phenomenon with a natural perspective (Kim et al., 2017). The researcher explains the role of communication in organizational conflict management.

A case study method can be interpreted as an outline or overall unit or case clearly defined (Ayuningtyas \& Prihatiningsih, 2017). The use of this case study can be seen in the analysis unit of the study. The analysis unit is intended for data related to the communication role of conflict management and organizational conflict between the Area Sales Manager and Sales Division in PT. Sinar Makmur Timur in Nusa Tenggara area.

The object of the study is a problem examined in research (Mukhtazar, 2020). The object of the study intended is how the communication role in conflict management between Sales Division and the Area Sales Manager in PT. Sinar Makmur Timur in Nusa Tenggara area. Then, the subject of the study is a resource person to obtain research data (Mukhtazar, 2020). The study interviewee is Timothius Richard Punuh as the Area Sales Manager and Syahril as the representative of the 
Sales Division.

Related to the effort in explaining the analysis unit validly, the researcheruses the triangulation of sources and theories. Sources triangulation is related to the data collection technique in the form of an indepth interview. As mentioned before, an in-depth interview was conducted using two interviewees. The data obtained from the interview were organizational conflict, conflict management, and organizational communication. Then, the triangulation theory refers to two or more theories to conduct data analysis comprehensively.

The data analysis technique conducted in this study involves four stages. Data collection was obtained by interview. After collected the interview result data, then those data would be reducted or sorted. The researcher sorted the information was obtained from the interview result and only collects the data related to the conflict, causes of conflict, conflict management strategy, and organizational communication adjusting the research analysis unit. The study's analysis elaborated on the organizational conflict, organizational conflict management, and specifically the role of communication in conflict management. From the explanation above, it can be known how the communication role in conflict management of PT. Sinar Makmur Timur in Nusa Tenggara area.

\section{RESULTS AND DISCUSSION Organizational Conflict}

Conflicts occurred in PT. Sinar Makmur Timur in Nusa Tenggara area was a group conflict between the Area Sales Manager as the leader and the Sales Division underneath. Conflicts that become the research subject belong to conflict between groups. The conflict between groups tends to occur in all organizational members as a part of the conflict. This form of conflict can be occurred in the industrial relationship (between organization and employees), between workgroups, and between workgroup members and its workgroup (Wirawan, 2010). Furthermore, the conflict between groups also occurs between the leader and the work unit underneath. In this study, conflict occurred between the Area Sales Manager as the leader and the Sales Division that becomes the work unit underneath. Thus, the conflict between groups becomes the object of the study.

The conflict occurred from Sales Division because the division did not do their job according to standard operating procedures (SOP), made their own decisions, and did not open with the Area Sales Manager. In understanding the conflict of incompatibility with standard operating, the following explanation can be seen in the table below:

Timothius Richard Punuh, as the Area Sales Manager, explained: "Sales do not do the operational and make their own decision. When the outlet requests something, there is no confirmation to us (Area Sales Manager and Sales Manager). If it is outside of Sales' decision, they usually are not confirmed to us. For example, the outlet requests a budget of around $10 \%$, they should confirm to the Sales Manager. If it is above $10 \%$, they just asked my solution. We have standards, for example, 12 outlets for hotel Sales. The visits are not $100 \%$ because the manager is not there or does not want to pay. In fact, the manager is there, but they do not want to wait. If there is a payment problem, they do not know if they do not visit,"

The cause of these conflicts come from the Sales Division, which does not do the SOP properly. Based on the interview results with Syahril as the interviewee from the Sales Division, the Division wants to finish their work and go home quickly. Syahril, as the Sales Division representative, explained: "Actually, it 
Yovita Marsha Listyono. The Role of Communication in Organizational Conflict...

is because the laziness and want to work quickly. So, we can go home quickly. We do not say to the boss because we are afraid if we are wrong". Moreover, the Sales Division also does not want to communicate with the boss if they have obstacles because they feel reluctant.

When the boss explained it, the Sales understand, but actually, they do not understand entirely. Based on the interview results with Timothius Richard Punuh, the conflicts impact the company, especially the distribution that does not run well, and the Nusa Tenggara area does not get the sales turnover.

The conflict between the Area Sales Manager and the Sales Division can be categorized as group conflict in an organization. The conflict is that the Sales Division does not do the SOP to have outlet visits to obtain the sales turnover. The Sales Division do that because they want to finish their job quickly. Moreover, the Sales Division also makes its own decision, and communication does not run well between both of them.

Those conditions can be explained by organizational conflict. The conflict occurs when actions and purposes are incompatible between individuals involved (Safitri et al., 2013). Those incompatibilities become the cause of conflict. Based on the explanation of interview results before, it showed that there are incompatibilities between the Area Sales Manager as the leader and the Sales Division underneath, especially the sales target achievements.

From the definition, the clash shows that Sales Division and Sales Manager have different actions to achieve the organizational goals in getting sales turnover. Sales Division ignore their job to get sales turnover. However, the Area Sales Manager depends on the Sales Division to get sales turnover so that the sales target can be fulfilled. The sales target will not reach if the Sales Division does not do their job according to the SOP, and it will become the conflict in PT. Sinar Makmur Timur in Nusa Tenggara area.

Wexley \& Yukl mentioned that the causes of conflict involve: (1) resources competition; (2) job dependency; (3) job field obscurity; (4) status problem; (5) communication obstacles; and (6) individual characters (Anaomi, 2014). The conflicts between the Area Sales Manager and Sales Division are caused by job dependency and communication obstacles. The sales turnover can be reached if the Sales Division conducts the visit and do the standard operational as in TABLE 1 . The company and the company's Area Sales Manager

TABLE 1. The Comparison between Standard Operating and Reality

\begin{tabular}{|c|c|}
\hline Standard Operating Procedure (SOP) & Reality \\
\hline $\begin{array}{l}\text { 1. The standard of daily visits by the Sales } \\
\text { Division is } 15 \text { outlets and a minimum of } 12 \\
\text { outlets making transactions. }\end{array}$ & $\begin{array}{l}\text { Sales Division does not make a visit standard } \\
\text { (less than } 15 \text { outlets). }\end{array}$ \\
\hline $\begin{array}{l}\text { 2. Sales Division reports the result of daily visits } \\
\text { to the Area Sales Manager. }\end{array}$ & $\begin{array}{l}\text { Sales Division does not report the result of } \\
\text { daily visits to the Area Sales Manager. }\end{array}$ \\
\hline $\begin{array}{l}\text { 3. The sales Division should confirm to the Area } \\
\text { Sales Manager first if the outlet has an offer } \\
\text { outside the company regulations. }\end{array}$ & $\begin{array}{l}\text { The Sales Division does not make } \\
\text { confirmation before and make their own } \\
\text { decision. }\end{array}$ \\
\hline
\end{tabular}

Sources: The Interview Results with Timothius Richard Punuh 
representative depends on the Sales Division's performance to reach its goals.

Those dependencies are seen a reciprocal dependence, which means the work unit's task output is exchanged back and forth (Wirawan, 2010). It means that sales target and distribution will be reached if the Sales Division can obtain sales turnover according to the target. Furthermore, vice versa, the Sales Division's outlet visit and searching for the sales turnover become the benchmark of PT. Sinar Makmur Timur in evaluating the distribution in Nusa Tenggara area. Thus, in this condition, the Area Sales Manager, who becomes the leader and the company's representative, depends on the Sales Division performance to get those turnover.

Sales Division also does not communicate to the Area Sales Manager about the obstacles faced and do not communicate that they do not understand the information received. It indicates poor communication by not open to the Sales Division with the Area Sales Manager. Sintesa Jablin mentioned that one of the problems between boss and subordinates is openness, which relates to organizational performance (Pace \& Faules, 2015). Sales Division feel reluctant with their boss so that they do not want to open in communicating.

The not open problem of the Sales Division showed that upward communication of PT. Sinar Makmur Timur in Nusa Tenggara area does not run well. Communication flows are more involved only by the boss to the subordinate. Another problem is that the Sales Division also make their own decision, which is not their authority.

\section{Conflict Management}

Louis Pondy elaborated five stages in organizational conflict: latent conflict, perceived conflict, felt conflict, manifest conflict, and conflict results
(Yuningsih, 2011). Latent conflict sees an incompatibility performance between the Area Sales Manager and the Sales Division in reaching the sales target. Sales Division does not do their job according to SOP and does not report to the Area Sales Manager. In contrast, the Area Sales Manager aims to reach the sales target determined by the company.

Those different goals become a problem because of the dependency. The Area Sales Manager depends on the Sales Division to reach the sales target. Sales Division performance that is not appropriate makes the sales target not achieved. This conflict problems change into a perceived conflict stage.

The conflict faced is directly solved. Based on the interview results with the Area Sales Manager, the conflict is directly solved because it will impact the consumer. Timothius explained that conflict is solved by inviting to talk with Sales Division. It is conducted because the sales team formed is not even a year when this research is conducted so that it needs more approach. Conflict is solved with the approach way of direct dialogue.

Timothius explained the conflict resolution: "Our Sales are not yet a year, so we have not given a written letter. It can be discussed first. If it is exaggerated and can not be controlled, then they will get a warning letter. In my opinion, chatting is better. So, I will approach directly,"

This condition has got into a felt conflict phase. The Area Sales Manager feels that there is a conflict. As the leader, he chooses to have a dialogue in solving the problems. Then, this strategy is applied in the next phase at the manifest phase. According to the conflict management strategy, conflicts are solved by combine three strategies, that are grid managerial by R.R. Blake \& Mouton, conflict management style by Thomas \& Kilmann, and integrative bargaining. R.R. Blake and J. Mouton 
Yovita Marsha Listyono. The Role of Communication in Organizational Conflict...

described the grid managerial theory that explained the concept of how a leader doing management activities. The grid managerial concept consists of country club, team management, middle of the road or organization man management, impoverished management, and task management or authority-obedience (Cai et al., 2019; Cho et al., 2018). Those grid managerial are related to the leader's behavior that is divided into caring for others (priority and necessity) and caring for production (according to the schedule) (Nahar, 2014).

The concept of Blake \& Mouton is developed by Nicotera, explained in two dimensions: assertiveness and cooperation (Nicotera \& Mahon, 2012). Nicotera's concept is refined back by Thomas \& Kilmann, which consist of competition style, collaboration, compromise, avoiding, and accommodation (Riasi \& Asadzadeh, 2015). The concept of grid managerial by Blake \& Mouton is developed into a conflict management style framework that consists of caring for self and caring for others.

The Area Sales Manager chooses using team management style and collaboration style in solving the conflict. Team management style care for production and subordinates. In contrast, the collaboration style cares for self and others. The use of both styles is shown by the Area Sales Manager, focusing on increasing sales turnover and paying attention to the Sales Division. However, the attention aims to the distribution process running properly to reach the turnover. Sales target achievement can be conducted if the conflict is solved by pay attention to the Sales Division.

The team management style is used by seeing the subordinates that they need to be cared for by having a dialogue. It is appropriate with the collaboration style, which also cares for others. The Area Sales Manager gives a chance to communicate with their subordinates. A collaboration style is used to prevent the development of a victim's role or behavior and prevent possible intimidation (Trudel \& Reio, 2011). The Area Sales Manager uses this style so that the Sales Division does not feel intimidates but feels cared for by their boss.

Rubin \& Brown elaborated that bargaining is a process related to someone's attempt to solve what they can give and take in their transaction (Stoshikj, 2014)the available information and their chosen approach and behavior. When following a distributive approach, the parties are interested in maximization of the personal outcome so they may not be able to see the total potential of an integrated approach. Crucial requirements for the integrative negotiations are close cooperation and communication between the parties. These negotiation typesdistributive and integrative-are closely related to the negotiation behavior of the involved parties: competitive and cooperative. Commonly used competitive and cooperative tactics are mentioned in this work, followed by economic and social-psychological measures of negotiation behavior. The obstacles for reaching integrative agreements are summarized. The contributions of the negotiation support system (NSS). Bargaining can be divided into two that is distributive and integrative bargaining. Distributive bargaining is a negotiation process where both parties have opposite importance and try to obtain profit as much as possible from other parties (Stoshikj, 2014) the available information and their chosen approach and behavior. When following a distributive approach, the parties are interested in maximization of the personal outcome so they may not be able to see the total potential of an integrated approach. Crucial requirements for the integrative negotiations are close cooperation and communication between 
the parties. These negotiation typesdistributive and integrative-are closely related to the negotiation behavior of the involved parties: competitive and cooperative. Commonly used competitive and cooperative tactics are mentioned in this work, followed by economic and social-psychological measures of negotiation behavior. The obstacles for reaching integrative agreements are summarized. The contributions of the negotiation support system (NSS). Integrative bargaining is that both parties solve their problems are less competitive and assign the same goals (Stoshikj, 2014) the available information and their chosen approach and behavior. When following a distributive approach, the parties are interested in maximization of the personal outcome so they may not be able to see the total potential of an integrated approach. Crucial requirements for the integrative negotiations are close cooperation and communication between the parties. These negotiation typesdistributive and integrative-are closely related to the negotiation behavior of the involved parties: competitive and cooperative. Commonly used competitive and cooperative tactics are mentioned in this work, followed by economic and social-psychological measures of negotiation behavior. The obstacles for reaching integrative agreements are summarized. The contributions of the negotiation support system (NSS).

Dialogue shows that Sales Manager Ares also uses integrative bargaining by asking the obstacles faced and helping to give a solution so that the turnover achievement can be running. Integrative bargaining is chosen because the Area Sales Manager feels that it is still needed to approach Sales Division because the Sales team of Nusa Tenggara is recently formed and running. The Area Sales Manager chooses this bargaining because it is still needed to approach, especially communication since the Sales Division of Nusa Tenggara is recently formed.

On the other hand, the collaboration and team management style sees at the subordinates and the company represented by the Area Sales Manager. Conflict is solved by always profitable the Sales Manager as the company representative. The profits are in the organization's sales target for always reached, and the distribution runs well. The approach does not entirely care for the Sales Division but to achieve the sales target.

Sales Division also has to do their job according to the SOP. On the other hand, the Sales Division also obtains a solution from the Area Sales Manager through the open dialogue to do their job according to the applicable procedure. It means that the communication is not completely open communication, but has its own goals in implementing its function and purpose.

After that, the conflict is solved by a win-win solution. The Area Sales Manager gives a solution to the Sales Division so that the job will still running. The sales Division also can communicate the obstacles felt. The result of conflict explains the post-conflict phase. After the conflict is over, the communication between the Area Sales Manager and Sales Division becomes more open in the short term. However, it still possible that those conflicts will occur again in the future.

\section{The Role of Communication in Conflict Management}

It is viewed from the communication flow, the communication flow of PT. Sinar Makmur Timur in Nusa Tenggara area is tied sequentially according to organizational structure, from the Area Sales Manager to the Sales Manager and the Sales Division. The 
Yovita Marsha Listyono. The Role of Communication in Organizational Conflict...

information given to the Sales Division is in the form of SOP, visit procedure, and product information. However, the Sales Division can directly communicate with the Area Sales Manager about the obstacles faced.

Based on the interview results with Timothius Richard Punuh, the media used for communication is usually through telephone and briefing directly every morning. The product introduction is given by the catalog. Moreover, there is a roleplay that explains how to build a relationship with customers. Communication is conducted directly and indirectly, but more often conducted by the Area Sales Manager to Sales Division than vice versa.

The explanation of organizational communication and conflict management reflects the communication role and organizational approach used by PT. Sinar Makmur Timur in Nusa Tenggara area. Conflict is considered a consequence of termination, damage, decline, or communication mistake (Aula \& Siira, 2010). Sales Division who do not have communication in the form of a report to the Area Sales Manager will become a conflict. This condiction also reflects the termination of communication from the Sales Division to the Area Sales Manager.

If it is viewed from the mechanistic paradigm, communication is interpreted as a mechanical process where the message across time and space (Rubino, 2019). This condition reflects an obstacle in communication between the Sales Division and the Area Sales Manager. The obstacle is referred to as not open in communicating. From that obstacle, communication can not run well and become a conflict.

Ruben explained that assumptions about communication would direct to the thinking of conflict concepts and influence someone in determining how to approach conflict (Aula \& Siira, 2010).
Communication becomes something important in conflict resolution between the Area Sales Manager and Sales Division marked by integrative negotiation and dialogue. The Area Sales Manager's point of view sees the importance of communication make them choose communication as conflict resolution.

Communication has a role as the conflict itself and becomes the facility in conflict resolution. It implies that communication in the conflict is in the form of not open communication between two parties. However, conflict resolution uses integrative bargaining and dialogue that make the re-established communication between them.

Liliweri mentioned that communication is key to an organization's or company's success, especially the open dialogue between superiors and subordinates because it will bring the opportunity changes (Haes \& Joniarta, 2020). Openness communication in the form of dialogue becomes an important key to conflict management. It means that open communication will not create conflict for the Area Sales Manager and Sales Division. Besides that, communication also has the main role in resolving the conflict and culminating in the company's relationship change. Conflict results of a win-win solution prove that the selection of dialogue approaches from the Area Sales Manager becomes effective in solving the conflict.

Then, the organizational communication approach used is more in the classical approach. PT. Sinar Makmur Timur for the Nusa Tenggara area sees that achieving goals of sales turnover is important. Miller elaborated that the classical approach emphasizes the rules immutability and procedure for organizational efficiency (Romadhan, 2018). The structure division of the Sales Division and Area Sales Manager is expected to achieve the company goals, 
especially the sales target. Sales targets that do not reach become a problem. The Area Sales Manager sees the Sales Division who do not reach the sales target as a conflict because it disturbs the running of the company as a distributor company.

Besides that, the Area Sales Manager also sees that the conflict impacts on the company. Conflict makes the company's function, and goals as a distributor company do not run well. It makes unequal distribution due to the visit absence and turnover from the Sales Division. Therefore, the Area Sales Manager chooses the team management style to approach Sales Division for always doing its goals and function.

The conflict in PT. Sinar Makmur Timur for the Nusa Tenggara area, the intended conflict is the classical approach itself. The classical approach is the method that can develop the productivity, efficiency, and effectiveness of the employee, along with their performance (Kitana, 2016). Sales target that is not achieved and unequal distribution show the failure of productivity development. Then, Sales Division performance that is not under the SOP also describes that the company does not run well. Failure in achieving focus can be defined as conflict according to the classical approach.

The classical approach also views conflict due to poor communication and a lack of trust between people involved in the conflict (Omisore \& Abiodun, 2014). The communication between the Area Sales Manager and Sales Division is not open. The lack of openness becomes an organizational conflict. As a part of the classical approach, communication and decision-making are also in the Area Sales Manager as the leader. Communication in the classical approach, especially communication from vertical and horizontal, aims to delegate authority, responsibility, instruction, and the subordinates required to report (Muhammad, 2014). Syahril, as the representative of the Sales Division, explained the information delivered to the superior related to: "Visit reports, obstacles in the field. Everything related to the job," Communication to the superior by Sales Division, is only obtained to report the job results in implementing visits, turnover attainment, and the outlets' obstacles only. It means that Sales Division only can communicate upward related to the procedure and job running.

Yuningsih explained that it is necessary to implement proper organizational communication in conflict management (Yuningsih, 2011). The conflict strategy arena model is called an objective, and conflict communication is a subjective view. Dani showed a relationship between organizational communication and conflict management showed a positive coefficient value (Dani, 2016). It means that good organizational communication skill also impacts on good conflict management.

It is different from the explanation from Yuningsih and Dani. This study emphasizes the deeper research about communication role in conflict management. Then, the communication has a role in conflict management as conflict and conflict resolution. Organizational communication becomes an important key to conflict, both from conflict started or conflict resolution. Apart from being related, this study proves that communication has a role as a core of conflict management.

\section{CONCLUSION}

From the result of the study explained before, it can be concluded that communication has a role in conflict management of PT. Sinar Makmur Timur in Nusa Tenggara area. The communication role is shown in the conflict and becomes the way of conflict 
Yovita Marsha Listyono. The Role of Communication in Organizational Conflict...

resolution. Communication is the core of conflict management.

Compared with the previous study, this study is explained the communication role in conflict management using the case study method. The results show that communication is also part of conflict management as a conflict and conflict resolution. Communication is not only related to conflict management but also has a strong role in conflict management as a core.

The researcher sees that the possibility of conflict occurring in the future can decrease if there is an openness from both parties. Dialogue and approach need to be conducted again, seeing the sales team formed recently. The Sales Division needs to open with superior and do the job according to applicable SOP. While the Area Sales Manager also needs to more approach the subordinate to minimize the conflict. The key to conflict management is communication that will build confidence in each other so that the communication will be more open and the chances of conflict being small.

\section{REFERENCES}

Anaomi. (2014). Strategi Komunikasi Persuasif Human Resources Development Dalam Menyelesaikan Konflik Karyawan Pt. Dimas Drillindo Cabang Duri Provinsi Riau. Jom Fisip, 1(2), 1-12.

Aula, P., \& Siira, K. (2010). Organizational communication and conflict management systems: A social complexity approach. Nordicom Review, 31(1), 125-141. https://doi. org/10.1515/nor-2017-0125

Ayuningtyas, F., \& Prihatiningsih, W. (2017). Komunikasi Terapeutik pada Lansia di Graha Werdha AUSSI Kusuma Lestari, Depok. Mediator: Jurnal Komunikasi, 10(2), 201-215. https:// doi.org/10.29313/mediator.v10i2.2911

Cai, D. A., Fink, E. L., \& Walker, C. B. (2019). Robert R. Blake, With Recognition of Jane S. Mouton. Negotiation and Conflict Management Research, 13(1), 1-9. https://doi.org/10.1111/ ncmr.12151

Cho, K. W., Yi, S. H., \& Choi, S. O. (2018). Does Blake and Mouton's managerial grid work?: the relationship between leadership type and organization performance in South Korea. International Review of Public Administration, 23(2), 103-118. https://doi.org/10.1080/12294659.201 8.1471029

Dani, A. K. (2016). Hubungan Komunikasi Organisasi dan Komitmen Manajemen Konflik pada Guru di Sekolah Islam Bunga Bangsa Samarinda. E-Jurnal Psikologi, 4(2), 189-199.

Haes, P. E., \& Joniarta, I. W. (2020). Organization Communication: Internal Conflict In Hospitality Industri. Mediator: Jurnal Komunikasi, 13(2), 101-107. https://doi.org/https://doi. org/10.29313/mediator.v13i1.5636

Kim, H., Sefcik, J. S., \& Bradway, C. (2017). Characteristics of Qualitative Descriptive Studies: A Systematic Review. Research in Nursing \& Health, 40(1), 23-42. https://doi.org/10.1002/ nur.21768.Characteristics

Kitana, A. (2016). Overview of the Managerial Thoughts and Theories From the History: Classical Management Theory to Modern Management Theory. Indian Journal of Management Science (Ijms), 6(1), 16-21.

Muhammad, A. (2014). Komunikasi Organisasi. Jakarta: Bumi Aksara.

Mukhtazar. (2020). Prosedur Penelitian Pendidikan. Jakarta: Absolute Media.

Nahar, L. (2014). Understanding of the Use of Blake \& Mouton's Model as a Tool for Analysing and Improving Management of Conflict in Organisations. International Journal of Research in Social Sciences, 4(4), 44-55.

Nicotera, A. M., \& Mahon, M. M. (2012). Between Rocks and Hard Places: Exploring the Impact of Structurational Divergence in the Nursing Workplace. Management Communication Quarterly, 27(1), 90-120. https://doi. 
org $/ 10.1177 / 0893318912458214$

Omisore, B. O., \& Abiodun, A. R. (2014). Organizational Conflicts: Causes, Effects, and Remedies. International Journal of Academic Research in Economics and Management Sciences, 3(6), 118-137. https://doi.org/10.6007/ ijarems/v3-i6/1351

Onwuegbuzie, A. J., Leech, N. L., \& Collins, K. M. T. (2012). Qualitative analysis techniques for the review of the literature. Qualitative Report, 17(56), $1-28$.

Pace, W., \& Faules, D. F. (2015). Komunikasi Organisasi: Strategi Meningkatkan Kinerja Perusahaan. Bandung: Remaja Rosdakarya.

Riasi, A., \& Asadzadeh, N. (2015). The relationship between principals' reward power and their conflict management styles based on ThomasKilmann conflict mode instrument. Management Science Letters, 5(6), 611-618. https://doi.org/10.5267/j. msl.2015.4.004

Romadhan, M. I. (2018). Pendekatan Komunikasi Organisasi Dalam Penyampaian Kebijakan Kantin Bebas 5P (Pewarna, Penyedap, Pemanis, Pengawet, dan Perasa) di SMP Negeri 7 Surabaya. Jurnal Riset Komunikasi, 1(2), 254-263. https:// doi.org/10.24329/jurkom.v1i2.38

Rubino. (2019). Konseptualisasi Mekanistis dalam Perspektif Komunikasi. Hikmah, 13(1), 134-150. https://doi.org/https:// doi.org/10.24952/hik.v13i1.1336

Safitri, R., Burhan, O. K., \& Zulkarnain. (2013). Gaya Manajemen Konflik dan Kepribadian. Psikologia: Jurnal Pemikiran Dan Penelitian Psikologi, 8(2), 39-49. https://doi.org/10.32734/ psikologia.v8i2.6576

Stoshikj, M. (2014). Integrative and distributive negotiations and negotiation behavior. Journal of Service Science Research, 6(1), 29-69. https://doi.org/10.1007/s12927-0140002-8

Trudel, J., \& Reio, T. (2011). Managing Workplace Incivility: The Role of Conflict Management Styles Antecedent or Antidote? Human Resources Development Quarterly, 22(4), 395-423. https://doi.org/https:// doi.org/10.1002/hrdq.20081

Wirawan. (2010). Konflik dan Manajemen Konflik: Teori, Aplikasi, dan Penelitian. Jakarta: Salemba Humanika.

Yuningsih, A. (2011). Implementasi Komunikasi Organisasi dalam Manajemen Konflik. Jurnal Sosial, Ekonomi, Dan Humaniora, 2(1), 195202. 